\title{
A novel method to determine the antiviral efficacy of hand rubs using murine norovirus (MNV) as surrogate of human norovirus
}

\author{
G Kampf $^{1 *}$, E Steinmann², J Steinmann ${ }^{3}$ \\ From International Conference on Prevention \& Infection Control (ICPIC 2011) \\ Geneva, Switzerland. 29 June - 2 July 2011
}

\section{Introduction / objectives}

So far there is no method available in Europe to determine the antiviral efficacy on contaminated hands. Aim was therefore to develop a method which resembles both contamination and hand treatment in clinical practice as closely as possible.

\section{Methods}

Each fingerpad (8 fingers per 4 subjects) was contaminated by dipping for $15 \mathrm{~s}$ in $0.4 \mathrm{ml}$ of MNV suspension $+10 \%$ stool suspension and allowed to dry. The virus titre on fingers was determined by shaking a plastic vial with $1 \mathrm{ml}$ of sampling fluid for $20 \mathrm{~s}$. Infectivity was determined by transferring $100 \mu \mathrm{l}$ after dilution to 8 wells of a microtitre plate with $100 \mu \mathrm{l}$ of $R A W 264.7$ cells. After 4 days cultures were assessed for cytopathic effects, the infective dose was calculated with the method of Spearman and Kärber. Hands were similar to EN 1500 either treated with $3 \mathrm{ml}$ of a hand rub or with $3 \mathrm{ml}$ of water of standard hardness using responsible application. Four hand rubs (based on ethanol 80\%, 85\% or $95 \%$, or based on a combination of $30 \%$ propan-1-ol, $45 \%$ propan-2-ol and $0.2 \%$ mecetronium etilsulphate) and one hand gel (based on $85 \%$ ethanol) were evaluated.

\section{Results}

Mean baseline viral titre was between 5.99 and 6.52. The ethanol-based products reduced the viral load by $4.32 \pm$ 0.69 ( $80 \%$ ethanol), $4.59 \pm 0.36$ (85\% ethanol, rinse), $4.52 \pm 0.67$ (85\% ethanol, gel) and $4.44 \pm 1.07(95 \%$ ethanol) which were all significantly more effective compared to the application of water (means between $2.29 \pm 0.45$ and $2.67 \pm 0.61$ ). The propanol-based hand rub was somewhat less effective $(3.77 \pm 0.66)$.

\section{Conclusion}

The new method allows determining the efficacy of hand rubs against MNV. The contamination is clinically relevant, the application of a hand rub is done as in patient care, the negative control allows determining the reproducibility.

\section{Disclosure of interest}

G. Kampf Employee of Bode Chemie GmbH, Hamburg, Germany, E. Steinmann Consultant for Mikrolab $\mathrm{GmbH}$, Bremen, Germany, J. Steinmann Employee of Mikrolab GmbH, Bremen, Germany.

\section{Author details \\ ${ }^{1}$ Scientific Affairs, Bode Chemie GmbH, Hamburg, Germany. ${ }^{2}$ Division of Experimental Virology, TWINCORE, Hannover, Germany. ${ }^{3}$ Mikrolab GmbH, Bremen, Germany.}

Published: 29 June 2011

doi:10.1186/1753-6561-5-S6-P27

Cite this article as: Kampf et al:: A novel method to determine the antiviral efficacy of hand rubs using murine norovirus (MNV) as surrogate of human norovirus. BMC Proceedings 2011 5(Suppl 6):P27.

${ }^{1}$ Scientific Affairs, Bode Chemie GmbH, Hamburg, Germany

Full list of author information is available at the end of the article

(c) 2011 Kampf et al; licensee BioMed Central Ltd. This is an open access article distributed under the terms of the Creative Commons Attribution License (http://creativecommons.org/licenses/by/2.0), which permits unrestricted use, distribution, and reproduction in any medium, provided the original work is properly cited. 